\title{
Mercury levels in seabirds and their fish prey at the Ebro Delta (NW Mediterranean): the role of trawler discards as a source of contamination
}

\author{
J. M. $\operatorname{Arcos}^{1, *}$, X. Ruiz ${ }^{1}$, S. Bearhop ${ }^{2}$, R. W. Furness ${ }^{2}$ \\ ${ }^{1}$ Departament de Biologia Animal, Universitat de Barcelona, Avenida Diagonal 645, 08028 Barcelona, Spain \\ ${ }^{2}$ Ornithology Group, Institute of Biomedical and Life Sciences, Graham Kerr Building, University of Glasgow, \\ Glasgow G12 8QQ, United Kingdom
}

\begin{abstract}
We determined mercury levels in internal tissues and feathers from corpses of Audouin's Larus audouinii and yellow-legged gulls L. cachinnans michaellis, common terns Sterna hirundo and European shags Phalacrocorax aristotelis desmarestii, as well as from fish representative of trawler discards, collected at the Ebro Delta (NW Mediterranean) between March and July (seabird's breeding season) in 1997 to 1999. The levels of mercury were significantly lower in epipelagic (Clupeiforms) than in demersal fish. When representation of each species in the discards is taken into account, the mean mercury concentration from this resource is more than double that of epipelagic fish (the main natural prey for most seabirds in the area). The shag was the only species with direct access to benthic fish, as it can dive to the seabed, and shags presented high levels of mercury even though they do not feed on discards. The other seabirds showed mercury levels in accordance with their seasonal use of discards. Audouin's gull, which exploits discards extensively during the breeding season, had the highest levels in those tissues reflecting mercury intake during the breeding season (liver and 1st primary feathers). In contrast, the common tern makes little use of discards and presented the lowest levels of mercury. For those samples reflecting the intake of mercury during the winter (mantle feathers), when only the yellow-legged gull exploits discards extensively, this species presented the highest values. Audouin's gull and the common tern showed similarly low concentrations of mercury for this period. We conclude that consumption of discarded demersal fish strongly influenced mercury contamination of surface-feeding seabirds.
\end{abstract}

KEY WORDS: Biomonitoring $\cdot$ Diet $\cdot$ Heavy metals $\cdot$ Mediterranean $\cdot$ Seabird-fisheries interactions

\section{INTRODUCTION}

Mercury is a highly toxic, nonessential heavy metal, which is released into the environment by natural sources such as volcanic emissions, continental particulate and volatile matter, and fluxes from the marine environment (Nriagu 1989). In addition, anthropogenic emissions (e.g. from fossil fuel combustion, waste incineration, and chemical production processes) have

${ }^{*}$ Present address: Institut Mediterrani d'Estudis Avançats IMEDEA (CSIC-UIB), c/Miquel Marqués 21, 07190 Esporles, Mallorca, Spain. E-mail: jmarcos@porthos.bio.ub.es increased over the last 2 centuries, contributing twice the amount of mercury released by natural sources at present (Nriagu 1989, Thompson 1996, Cossa et al. 1997, Monteiro et al. 1999). This metal is of special concern for aquatic ecosystems, where inorganic mercury is efficiently biotransformed into organic forms (methylmercury) and accumulates in biota (Bryan 1979, Lindqvist 1991). Moreover, mercury increases in concentration up the aquatic food chain, a process termed biomagnification (Bryan 1979, Walsh 1990, Bearhop 2000a). In the oceans, methylation processes are especially important in subthermocline waters (mesopelagic environments), where inorganic mercury arrives mainly 
through atmospheric deposition (Mason \& Fitzgerald 1990, Cossa et al. 1994). As a consequence, mesopelagic organisms exhibit particularly high levels of mercury (Monteiro et al. 1996, 1998), and appear to have elevated tolerance to this metal (e.g. Thompson 1996). Mercury levels in these organisms are not directly related to acute human pollution events, and are quite constant at very broad scales (Monteiro et al. 1999). Coastal and estuarine areas seem to play a minor role in the global cycle of mercury. However, these areas can exhibit locally high levels of mercury directly resulting from human pollution, often associated with riverine inputs (Luoma 1990). In coastal polluted zones, mercury is readily deposited in sediments and is less bioavailable than in the open oceans (e.g. Nisbet 1994, Cossa et al. 1997), but is still incorporated into local food chains to a significant degree (e.g. Mikac \& Picer 1985, Braune 1987, Furness et al. 1995). Moreover, coastal organisms tend to have lower tolerance to mercury than those in mesopelagic environments as the background levels of mercury in coastal waters are usually much lower (e.g. Thompson 1996).

The high toxicity of mercury and the increase of this metal in the environment resulting from human activities have emphasised the necessity of monitoring its levels, both spatially and temporally (e.g. Scheuhammer 1987, Furness 1993). In aquatic ecosystems this has often been done using live organisms as monitoring tools, given the complex behaviour of mercury in these environments (which includes several biologically mediated processes), as well as its property of biomagnification. In this respect, seabirds are appropriate for several reasons, such as high trophic position (thus reflecting integrated mercury levels over the whole food chains), and relatively well known biology (Walsh 1990, Furness 1993). In addition, increasing knowledge of mercury dynamics in seabirds allows the interpretation of their mercury levels with some confidence (e.g. Monteiro et al. 1998). Mercury dynamics includes assimilation from the diet, accumulation in internal tissues (mainly the liver) and redistribution during moult periods to the growing feathers (Furness et al. 1986, Honda et al. 1986, Braune \& Gaskin 1987, Monteiro \& Furness 2001). Hence, mercury levels in the different seabird tissues are considered to ultimately reflect dietary input (e.g. Leonzio et al. 1986, Braune 1987, Monteiro et al. 1998, Bearhop 2000a). However, factors such as the moult pattern and the migratory habits of the different seabird species often obscure this relationship and should be taken into account, with considerations varying in accordance with the tissue selected (Walsh 1990, Furness 1993). As the body pool of mercury is excreted into the growing feathers during moults, internal tissues would reflect mercury levels accumulated from the end of the last moult to the moment of collection. In turn, feathers would reflect levels of mercury accumulated between moults, with feathers grown in different moults reflecting different periods.

Given the importance of the diet in explaining interand intraspecific differences in mercury levels of seabirds, research efforts should be directed at ascertaining the content of mercury both in diet samples and in a wide range of potential prey (cf. Monteiro et al. 1998). In addition, it is important to assess the feeding ecology of the seabird species selected for study (e.g. Monteiro et al. 1999). Within this context, the increasing use of fishery waste by several seabird populations through the last century (e.g. Furness et al. 1992, Garthe et al. 1996, Oro 1999, Tasker et al. 2000) should be considered as a potential extra source of mercury in some cases, as this has led to important changes in their diets. Indeed, seabirds exploiting discards and offal have access to species otherwise unavailable to them (Furness et al. 1988), which could expose them to higher levels of mercury than those found in their natural prey. This would be the case when discards are composed of either demersal fish (unavailable to surface-feeding seabirds) or mesopelagic fish (unavailable to both inshore and diurnal species, in the latter case because mesopelagic organisms are subject to diel vertical migrations and are available from the surface only at night; e.g. Whitehead et al. 1986). In the present study, we tested the hypothesis that trawler discards can provide extra mercury to some seabird species. In order to do this, we determined mercury levels in seabird tissue samples (feathers, liver, kidney) and discards collected off the Ebro Delta (NW Mediterranean) during the seabirds' breeding season. Four seabird species were selected for analysis, differing in both their feeding ecology and their relative use of discards: Audouin's Larus audouinii and the yellow-legged gulls $L$. cachinnans michaellis, the common tern Sterna hirundo and the European shag Phalacrocorax aristotelis desmarestii. By sampling soft tissues and feathers grown at particular times of year, we were able to investigate seasonal changes in mercury contamination that might relate to seasonal changes in diet. In the case of fish, 15 species representative of discards were selected, including the typical natural prey for most of the seabirds (i.e. epipelagic fish). We predicted that: (1) demersal fish would have higher levels of mercury than epipelagic fish, due to the former's usually longer life-span, higher trophic level, and proximity to bottom sediments; (2) discards would have higher average levels of mercury than typical fish prey of surface-feeding seabirds; (3) seabirds typically feeding upon discards would present higher levels of mercury than those more strictly feeding on 
epipelagic fish; and (4) seasonal differences in the diet and the feeding habits of the seabirds would lead to differences in the levels of mercury accumulated during different periods, and hence in the different feather or soft tissue samples that reflect intake over particular periods. Soft tissues would reflect mercury levels accumulated shortly before their collection (i.e. the breeding season), whereas feathers would reflect the mercury accumulated either during the winter (when replaced during the pre-breeding moult) or during the breeding season of the preceding year (when replaced during the post-breeding moult).

\section{MATERIALS AND METHODS}

Study area. The Ebro Delta $\left(40^{\circ} 43^{\prime} \mathrm{N}, 0^{\circ} 55^{\prime} \mathrm{E}\right.$; NW Mediterranean) is surrounded by a wide continental shelf, with high biological productivity resulting from the nutrients provided by the Ebro River and the mixing effect of the Liguro-proveçal-catalan front at the continental slope (Salat 1996). This area sustains one of the most important commercial fisheries of the Western Mediterranean, with both bottom trawler (demersal) and purse seine (pelagic) fishing fleets (Irzaola et al. 1996). At the same time, the area is home to one of the most important breeding seabird communities of the Mediterranean, with several species taking advantage of the discards provided by the local fisheries (Oro \& Ruiz 1997).
Samples. Between March and July of 1997 and 1998, fish samples were collected from the by-catch fraction of commercial trawlers operating off the Ebro Delta. After determining the composition of trawler discards ( $\mathrm{n}=$ 14 hauls, $36 \mathrm{~kg}$ examined, 3000 fish measured and weighed) we selected 15 fish species, which accounted for $91.4 \%$ in weight of the total fraction of discards consumable by seabirds and were considered representative of this fraction (see Table 1). These species were classified into 2 categories according to their distribution in the water column, their general ecology (Whitehead et al. 1986), and ultimately their natural availability to surface-feeding seabirds: epipelagic and nonepipelagic (demersal) fish. Epipelagic species comprised Clupeiforms, which feed mostly on plankton and spend an important fraction of the day close to the sea surface. These fish are considered to constitute the main natural prey for most seabird species in the study area, which basically are surface feeders (Oro 1999). Demersal fish tend to occupy higher trophic levels than epipelagic fish and inhabit greater mean daytime depths. Although rarely captured in a natural way by surface-feeding seabirds, trawler discards make these fish available to some species. Mesopelagic fish species only occasionally occurred in the discards and were not considered in the present study, as trawlers off the Ebro Delta rarely operate at depths greater than $200 \mathrm{~m}$. Each fish sample for mercury analysis was prepared by homogenising 2 to 10 fish of similar size. For each species, 5 samples were examined, trying to cover the range of

Table 1. Mercury concentrations (ng g dry wt ${ }^{-1}$ ) in fish species occurring in trawler discards in the Ebro Delta area. Five samples were examined for each species, each sample resulting of pooling between 2 and 10 fish of similar size. The total length of the fish analysed (mean $\pm \mathrm{SD}$ ) is provided. The table also shows the percentage in weight of the different fish species with respect to total discards and, in the case of epipelagic fish, also considering their relative abundance in the environment estimated from purse-seine captures

\begin{tabular}{|c|c|c|c|c|c|}
\hline \multirow{2}{*}{ Fish species/group } & \multicolumn{2}{|c|}{ Mercury } & \multirow{2}{*}{ Length (mm) } & \multicolumn{2}{|c|}{$\%$ in weight $\left(P_{i}\right)$} \\
\hline & Median/Mean & Range & & Discards & Environment \\
\hline Epipelagic & $138 / 147$ & $40-326$ & & & \\
\hline Sardine Sardina pilchardus & $76 / 77$ & $40-117$ & $133 \pm 10$ & 27.7 & 84.1 \\
\hline Anchovy Engraulis encrasicholus & $226 / 223$ & $138-326$ & $125 \pm 6$ & 11.7 & 10.3 \\
\hline Guilt sardine Sardinella aurita & $159 / 141$ & $82-182$ & $196 \pm 16$ & 0.2 & 5.6 \\
\hline Demersal & $253 / 362$ & $42-1136$ & & & \\
\hline Bogue Boops boops & $254 / 299$ & $91-474$ & $180 \pm 27$ & 29.6 & \\
\hline Poor cod Trisopterus minutus $C$. & $126 / 140$ & $42-235$ & $74 \pm 6$ & 3.3 & \\
\hline Silvery pout Gadiculus argenteus & $144 / 156$ & $108-229$ & $86 \pm 18$ & 2.6 & \\
\hline Blue whiting Micromesistius poutassou & $102 / 97$ & $73-126$ & $142 \pm 7$ & 2.0 & \\
\hline Hake Merluccius merluccius & $49 / 65$ & $45-93$ & $82 \pm 10$ & 1.8 & \\
\hline Brown comber Serranus hepatus & $503 / 478$ & $158-781$ & $86 \pm 6$ & 2.5 & \\
\hline Dragonet Callionymus maculatus & $365 / 354$ & $199-495$ & $80 \pm 17$ & 1.0 & \\
\hline Goby Deltenosteus quadrimaculatus & $822 / 830$ & $528-1136$ & $80 \pm 7$ & 1.2 & \\
\hline Black goby Gobius niger & $743 / 699$ & $449-934$ & $69 \pm 6$ & 1.2 & \\
\hline Spotted flounder Citharus macrolepidotus & $91 / 117$ & $85-194$ & $89 \pm 7$ & 1.5 & \\
\hline Scophtalmidae/Bothidae spp. & $291 / 364$ & $131-649$ & $79 \pm 13$ & 3.5 & \\
\hline Tongue sole Symphurus nigrescens & $740 / 745$ & $409-1110$ & $91 \pm 9$ & 1.6 & \\
\hline
\end{tabular}


sizes present in discards. Mercury concentrations were averaged for each fish species, and also for trawler discards as a whole. The average concentration for discards $\left([\mathrm{Hg}]_{\mathrm{D}}\right)$ was calculated as follows:

$$
[\mathrm{Hg}]_{\mathrm{D}}=\sum_{i=1}^{n}\left([\mathrm{Hg}]_{i} \times \frac{P_{i}}{\sum_{j=1}^{n} P_{j}}\right)
$$

where $[\mathrm{Hg}] \mathrm{i}$ is the mean concentration for species $i$, and $P_{i}$ and $P_{j}$ the representation (\%) by weight of species $i$ and $j$ in the discards (values shown in Table 1). Since the 15 fish species selected for analysis did not represent $100 \%$ of discards, we referred the average concentration of mercury in discards to this sub-fraction by dividing each $P_{i}$ by the sum of all $P_{j}$. This way, we assumed that the species selected for analyses were representative of the mercury concentration of the whole fraction of discards. Mercury concentrations were also averaged for epipelagic fish, following the above equation. In this case, $P_{j}$ reflected the relative abundance (\%) of each epipelagic species at sea, estimated from data of catches collected on board pelagic purse seiners (see Table 1; Arcos \& Oro 2002).

Seabird samples were obtained from corpses found at the Ebro Delta during spring/summer in 1997 to 1999. Of the 4 seabird species considered, Audouin's and the yellow-legged gulls make extensive use of discards (Oro \& Ruiz 1997), whereas the common tern and the shag were selected for their low attendance at trawlers. The samples selected for analysis were internal tissues (liver and kidney) and feathers (mantle and primary feathers). Mantle feathers were collected from all specimens (from the upper mantle region, close to the neck), while primary feathers where only analysed in Audouin's and yellow-legged gulls (1st-innermost-primary) and the common tern (1st and 7th primaries). As the gulls considered here perform a partial pre-breeding moult (body feathers and some coverts) and a complete post-breeding moult (including flight feathers; Grant 1986), we expected the individuals collected to have moulted the upper mantle feathers before the breeding season (thus reflecting winter levels of mercury) and the primaries after the preceding breeding season (thus reflecting mercury levels accumulated during the breeding period). The common tern is unusual among seabirds, since it moults its innermost primaries twice a year (Olsen \& Larsson 1995), and so when it reaches the breeding grounds it exhibits 2 generations of primaries. In this case, we expected the 1st primary (recently moulted) to reflect winter levels and the 7th primary (the innermost primary of the old generation) to reflect levels accumulated during the previous breeding season.
Juvenile birds were excluded from this study, as they usually show significantly lower mercury values than adults (Furness 1993). Starved individuals were also removed when considering internal tissues, as unusually high soft tissue concentrations of mercury can occur due to weight loss (Thompson 1996). Birds considered to have died of starvation were identified directly (e.g. unusually low weight either of internal tissues or for the whole bird) or through lipid extractions of liver tissue (with those birds exhibiting a particularly low proportion of extracted lipids being considered as starved).

Both fish and seabird samples were stored frozen at $-20^{\circ} \mathrm{C}$, immediately after their collection. Before mercury analysis, samples were homogenised and ovendried at $60^{\circ} \mathrm{C}$ to constant weight.

Mercury analysis. All samples were analysed for total mercury by atomic fluorescence spectrophotometry, following standard digestion (for details, see Bearhop et al. 2000a). Mercury concentrations are given on a dry weight basis as ng $\mathrm{g}^{-1}$ (equivalent to ppb) for fish and $\mu \mathrm{g} \mathrm{g}^{-1}$ (ppm) for seabirds, in order to facilitate their interpretation and their comparison with other studies. Detection limits on a typical run (10 $\mathrm{ng} \mathrm{g}^{-1}$ calibration) were less than $0.1 \mathrm{ng} \mathrm{g}^{-1}$, which is an order of magnitude lower than the lowest concentrations measured in the study. Precision and accuracy of the method were tested using standard reference materials (TORT-2 lobster hepatopancreas $\pm 95 \%$ confidence interval $=$ $0.26 \pm 0.03, \mathrm{n}=17$, certified value $=0.27 \pm 0.06)$ and replicate samples.

Statistics. Mercury concentrations of both fish and seabirds were tested for normality using the ShapiroWilk's test (see Zar 1996). Normality was violated in several cases, which could be due in part to low sample size, as well as to the typical skewness of the distributions of mercury levels (Walsh 1990). Thus, we adopted

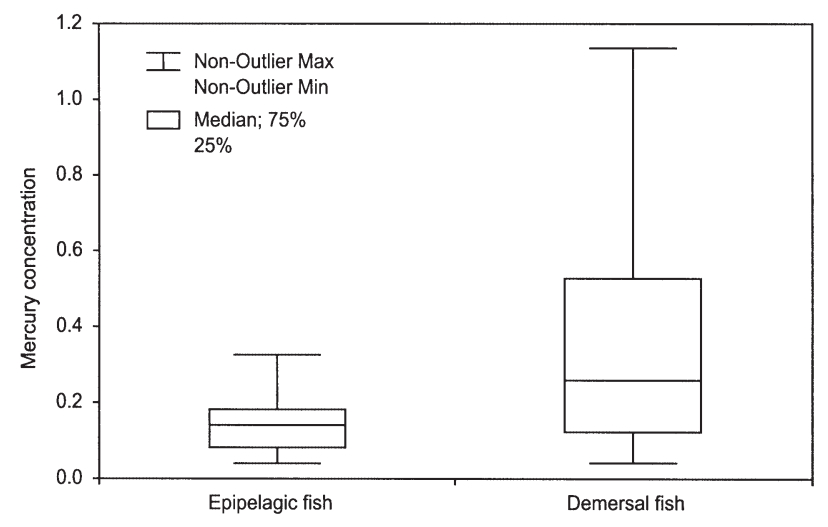

Fig. 1. Comparison of the levels of mercury ( $\left.\mu g g d_{r y} t^{-1}\right)$ between epipelagic ( $\mathrm{n}=15$ samples, 3 species involved) and demersal fish $(\mathrm{n}=60$ samples, 12 species) 
Table 2. Mercury concentrations ( $\mu g g$ dry $\mathrm{wt}^{-1}$ ) in different tissues of the seabird species considered for analysis (kidney, liver, $\mathrm{MF}=$ mantle feathers, $\mathrm{P} 1=1$ st primary feathers, $\mathrm{P} 7=7 \mathrm{th}$ primary feathers). Sample size is also provided (n)

\begin{tabular}{|c|c|c|c|}
\hline \multirow{2}{*}{$\begin{array}{l}\text { Species } \\
\text { Tissue }\end{array}$} & \multirow[b]{2}{*}{$\mathrm{n}$} & \multicolumn{2}{|c|}{ Mercury } \\
\hline & & Median/Mean & Range \\
\hline \multicolumn{4}{|c|}{ Audouin's gull Larus audouinii } \\
\hline Kidney & 7 & $3.51 / 4.33$ & $0.68-8.06$ \\
\hline Liver & 23 & $6.53 / 8.36$ & $1.46-22.26$ \\
\hline $\mathrm{MF}$ & 40 & $0.84 / 1.27$ & $0.29-5.18$ \\
\hline P1 & 30 & $7.87 / 8.10$ & $2.03-14.07$ \\
\hline \multicolumn{4}{|c|}{ Yellow-legged gull Larus cachinnans m. } \\
\hline Kidney & 11 & $2.05 / 2.17$ & $0.82-4.28$ \\
\hline Liver & 13 & $2.55 / 2.98$ & $0.95-5.91$ \\
\hline MF & 14 & $1.49 / 2.10$ & $0.75-4.36$ \\
\hline P1 & 3 & $7.38 / 7.00$ & $3.84-9.79$ \\
\hline \multicolumn{4}{|c|}{ Common tern Sterna hirundo } \\
\hline Liver & 5 & $1.01 / 0.99$ & $0.63-1.24$ \\
\hline MF & 5 & $0.76 / 0.92$ & $0.54-1.54$ \\
\hline P1 & 5 & $0.84 / 1.05$ & $0.79-1.52$ \\
\hline P7 & 5 & $1.63 / 2.09$ & $0.92-3.31$ \\
\hline \multicolumn{4}{|c|}{ Shag Phalacrocorax aristotelis $d$. } \\
\hline Kidney & 3 & $7.50 / 5.60$ & $1.56-7.74$ \\
\hline Liver & 3 & $6.58 / 5.32$ & $2.42-6.97$ \\
\hline MF & 3 & $2.52 / 2.45$ & $0.69-4.12$ \\
\hline
\end{tabular}

the more conservative non-parametric statistics in most cases, following Zar (1996). The significance level was held at 0.05, although marginal values are also discussed following Stoehr (1999).

\section{RESULTS}

Mercury levels of the fish species examined are given in Table 1, along with the mean length of the individuals sampled in each case. As a rule, epipelagic fish showed lower levels than demersal fish (MannWhitney test, $U_{60,15}=263, p=0.01$; Fig. 1). Taking into account the contribution by weight of each fish species

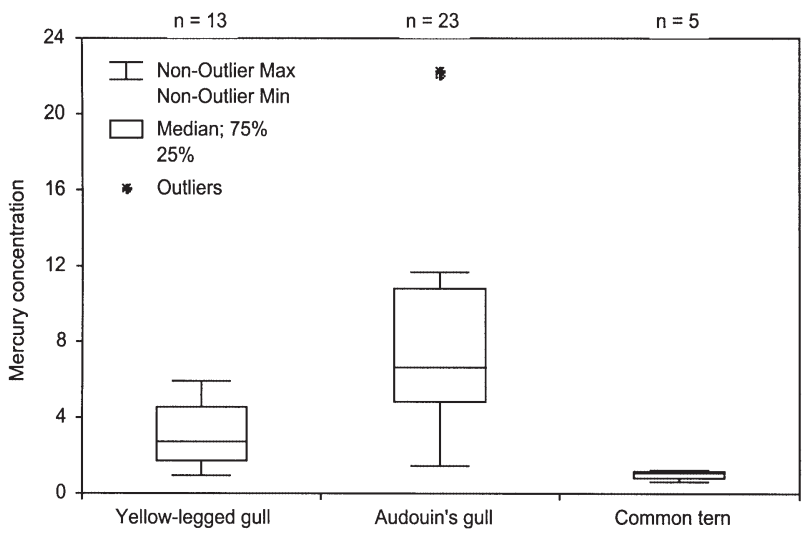

Fig. 2. Interspecific comparison of the levels of mercury ( $\mu \mathrm{g} \mathrm{gdry} \mathrm{gt}^{-1}$ ) in the liver tissue of seabirds (assumed to reflect dietary input throughout the breeding season). The shag is not included due to low sample size (n, sample size)

to the discards (Table 1), we estimated a mean mercury concentration of $228 \mathrm{ng} \mathrm{g}^{-1}$ in this source of food for seabirds. In the case of epipelagic fish, this value was lower, $96 \mathrm{ng} \mathrm{g}^{-1}$ when considering the relative abundance of each species at sea.

At the species level, the concentration of mercury increased with the length of the fish, although for most species this relationship was not statistically significant (Spearman's correlation), probably due to low sample sizes. However, correlation coefficients were high and in all cases positive (median $=0.66$, range $=0.19$ to $0.90)$, which suggests that this trend was consistent.

The mercury levels measured in internal tissues and feathers of the different seabird species are shown in Table 2, and correlations between the different tissues appear in Table 3. Mercury levels in the kidney were strongly correlated with those in the liver, despite the former being lower than the latter. Thus, given the smaller sample size available in kidney tissues, only liver tissues were considered in further analyses, as representative of internal tissues.

Table 3. Correlation between mercury levels of the different samples of seabirds here considered (kidney, liver, MF $=$ mantle feathers, $\mathrm{P} 1=1$ st primary feathers, $\mathrm{P} 7=7 \mathrm{th}$ primary feathers). Correlations were not performed when sample size (n) was lower than 5. $\mathrm{r}_{\mathrm{S}}=$ Spearman's correlation coefficient; $\mathrm{p}=$ statistical significance (2-tailed test)

\begin{tabular}{|c|c|c|c|c|c|c|c|c|c|}
\hline & \multicolumn{3}{|c|}{ Yellow-legged gull } & \multicolumn{3}{|c|}{ Audouin's gull } & \multicolumn{3}{|c|}{ Common tern } \\
\hline & $\mathrm{n}$ & $\mathrm{r}_{\mathrm{S}}$ & $\mathrm{p}$ & $\mathrm{n}$ & $\mathrm{r}_{\mathrm{S}}$ & $\mathrm{p}$ & $\mathrm{n}$ & $\mathrm{r}_{\mathrm{S}}$ & $\mathrm{p}$ \\
\hline Liver-kidney & 11 & 0.91 & 0.0001 & 7 & 0.86 & 0.01 & - & - & - \\
\hline Liver-MF & 12 & -0.09 & 0.78 & 21 & 0.24 & 0.29 & 5 & 0.70 & 0.19 \\
\hline Liver-P1 & - & - & - & 16 & 0.37 & 0.16 & 5 & 0.30 & 0.62 \\
\hline Liver-P7 & - & - & - & - & - & - & 5 & 0.50 & 0.39 \\
\hline MF-P1 & - & - & - & 27 & 0.24 & 0.2 & 5 & 0.80 & 0.10 \\
\hline MF-P7 & - & - & - & - & - & - & 5 & 0.60 & 0.28 \\
\hline P1-P7 & - & - & - & - & - & - & 5 & 0.40 & 0.50 \\
\hline
\end{tabular}


Audouin's gull, the yellow-legged gull and the common tern showed clear differences in the mercury concentration of liver tissues, which were assumed to represent the body levels in the breeding season (Kruskal-Wallis test, $H_{2,41}=23.8, \mathrm{p}<0.0001$; Fig. 2). Post hoc analyses (Mann-Whitney test) showed significant differences in all cases, with Audouin's gull presenting the highest levels and the common tern the lowest. The shag was not considered in the previous analyses due to low sample size, but presented high levels of mercury in the liver, comparable to those of Audouin's gull (Table 2). The 1st primary feathers of Audouin's and yellow-legged gulls and the 7th primary feathers of common terns were also assumed to reflect mercury levels accumulated during the breeding season, but in the previous year. In the case of Audouin's gull, mercury levels did not significantly differ between the 1 st primary and liver tissues $\left(U_{23,30}=311.0, \mathrm{p}=\right.$ 0.54 ), while in the common tern the levels of mercury in the 7 th primary were slightly higher than in the liver $\left(U_{5,5}=37.0, \mathrm{p}=0.05\right)$. For the yellow-legged gull, the 1st primary also appeared to present higher levels than the liver, although the few primaries collected prevented any statistical comparison. In any case, the interspecific pattern for mercury in primary feathers was similar to that showed by livers, with Audouin's gull presenting considerably higher levels of mercury than the common tern $\left(U_{5,30}=0, \mathrm{p}=0.0005\right)$, and the yellowlegged gull being at an intermediate position. Audouin's gull showed the highest variability in the levels of mercury in both liver tissues and the primaries, while the common tern presented very low variation (Fig. 2).

Mantle feathers, assumed to reflect the mercury accumulated in the winter, showed a different interspecific pattern to that observed with the livers and the

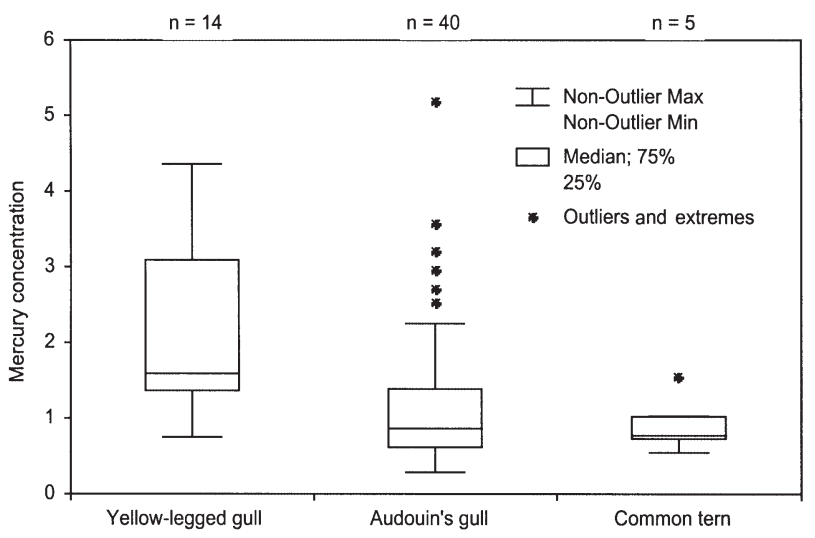

Fig. 3. Interspecific comparison of the levels of mercury $\left(\mu \mathrm{g} \mathrm{g} \mathrm{dry} \mathrm{wt^{-1 }}\right.$ ) in the mantle feathers of seabirds (assumed to reflect dietary input throughout the non-breeding season). The shag is not included due to low sample size (n, sample size) primary feathers. Indeed, in this case the yellowlegged gull presented the highest levels of mercury, while Audouin's gull and the common tern showed relatively low levels $\left(H_{2,58}=11.1, \mathrm{p}=0.004\right.$; Fig. 3$)$. Post hoc analyses did not show differences between Audouin's gull and the common tern, while both species significantly differed in mercury levels from those presented by the yellow-legged gull. The 1st primary of common terns, also assumed to reflect winter levels of mercury, had values very similar to those of mantle feathers $\left(U_{5,5}=32, \mathrm{p}=0.35\right.$; Table 2$)$.

\section{DISCUSSION}

In accordance with our predictions, demersal fish showed higher levels of mercury than epipelagic fish, and this was reflected in the high average concentration of this metal in trawler discards. Indeed, mercury levels in discards were more than double those found in epipelagic fish. Among demersal fish (mesopelagic species were not considered in this study), the highest values corresponded to the most strictly benthic species (gobys Gobiidae, dragonets Callionymidae, brown comber Serranus hepatus, and flatfish Pleuronectiformes). Some of these fish exhibited unexpectedly high concentrations of mercury (mean specific values up to $830 \mathrm{ng} \mathrm{g}^{-1}$ ), exceeding those reported for similar sized mesopelagic fish from the Azores (mean values below $400 \mathrm{ng} \mathrm{g}^{-1}$; Monteiro et al. 1996). This does not necessarily contradict the fact that mesopelagic biota present the highest values of mercury in marine environments (Monteiro et al. 1996, 1998), but may rather reflect the high methylation rate detected in the Mediterranean (6-fold over that of the North Atlantic; Cossa et al. 1997). Indeed, Mediterranean biota is known to have high levels of mercury in comparison to equivalent biota in the Atlantic, as has been reported in several studies (e.g. Lambertini \& Leonzio 1986, Osborn 1988, Renzoni et al. 1998). In addition to natural inputs, local pollution in the study area could explain the unusually high concentrations of mercury even for a Mediterranean context. This seems to be the case, given the important inputs from the Ebro River (with a high development of agricultural and industrial activities along its watershed) and the nearby chemical industry (cf. Morera et al. 1997, Sanchiz et al. 2000, Sanpera et al. 2000).

Several studies have found a direct relationship between size (i.e. age) and mercury concentrations in fish (see Thompson 1990, and references therein). This was the case in our study when comparing within species, yet small species usually had higher levels of mercury than large species. This is likely to be an age effect. Fishermen only discard young individuals of 
some large, commercial species (e.g. the silvery pout Micromesistius poutassou and the hake Merluccius merluccius). These individuals, in spite of being larger than adults of smaller species, apparently have accumulated less mercury throughout their shorter life. Moreover, although adult silvery pout and hake may occupy mesopelagic environments, they have more coastal distributions when young (Whitehead et al. 1986), thus incorporating less mercury at this stage.

Heavy metals tend to be held in one particular tissue at much higher levels than in others, and this has an important influence on the choice of tissue for monitoring studies (Furness 1993). In seabirds, dietary mercury is incorporated in a dose-dependent manner (Lewis \& Furness 1991), and is accumulated in internal tissues (mainly in the liver and the kidney) between moult periods, ultimately being excreted to the growing feathers during moults (Furness et al. 1986, Honda et al. 1986, Braune \& Gaskin 1987, Monteiro \& Furness 2001). In accordance with that, the strongest correlation in mercury concentration between tissues of birds was between liver and kidney tissues, which should reflect the same period of mercury accumulation (cf. Walsh 1990). Mercury levels in mantle feathers and the 1st primary of common terns were also well correlated, although not significantly, and were the only feathers grown during the same period (pre-breeding moult). Feathers moulted during the pre-breeding moult did not show any clear relationship with either liver tissues or feathers grown after the post-breeding moult. Intermediate results were obtained for the correlation between internal tissues and feathers grown in the post-breeding moult, as these samples should reflect mercury levels incorporated in the same season but in different years, and inter-year variation is likely to have an influence. The observed correlations are therefore as would be predicted on the basis of the known kinetics of mercury in birds (Monteiro \& Furness 2001).

Despite sometimes difficult to prove, inter- and intraspecific differences of mercury levels in seabirds are considered to be mainly determined by the diet (e.g. Leonzio et al. 1986, Braune \& Gaskin 1987, Monteiro et al. 1998, Bearhop et al. 2000a), although interand intraspecific variability in excretion rates may also play a role (Monteiro et al. 1998, Bearhop et al. $2000 \mathrm{~b}, \mathrm{c})$. In this study, diet composition seems to be the main determinant of mercury levels in different seabird species, with mercury levels being higher in those species consuming discards (i.e. demersal fish). The only exception to this trend was that of the shag, which presented relatively high levels of mercury despite rarely consuming discards (cf. Oro \& Ruiz 1997). However, this result was to be expected as the shag is the only species of those considered here that has direct access to benthic fish because it can dive to the seabed. In the case of the gulls and the common tern, the relationship between mercury levels and use of discards was evident. Indeed, during the breeding season Audouin's gull preferentially feeds on discards (Oro et al. 1997), although it also captures epipelagic fish to a variable degree, and showed correspondingly high levels of mercury in the summer liver samples. The yellow-legged gull combines discards with foods of terrestrial and freshwater origin (Oro et al. 1995), the latter presenting negligible amounts of mercury compared to marine prey (e.g. Leonzio et al. 1986, Thompson 1996), and this species presented high levels of mercury yet significantly lower than those exhibited by Audouin's gull. Finally, the common tern basically feeds on Clupeiforms ( $>90 \%$ of its prey; A. Hernández pers. comm.) and levels of mercury in this species were correspondingly lower. Moreover, the tern captures fish considerably smaller than those either present in the discards or captured by Audouin's gull in a natural way, thus incorporating even less mercury than larger seabirds would do when feeding on larger (i.e. more contaminated) Clupeiforms. The 2 gulls present more plasticity in their diet than the common tern, and concordantly showed more variability in their levels of mercury. Considering the detailed dietary composition of Audouin's and the yellowlegged gulls under different fishing regimes (Oro et al. $1995,1997)$, we estimated an average input of mercury 2.4 times higher for the former, at the Ebro Delta, during the breeding season. This value is very close to the ratio of mercury levels between both species, 2.6 for the liver, which supports the link between diet and concentrations of this metal. Similar ratios have been obtained in other Mediterranean colonies (e.g. Leonzio et al. 1989), with an extreme value of 10 when comparing mercury levels in eggs of yellow-legged gull from the Medes Islands (NW Mediterranean) with those of Audouin's gull from the Ebro Delta (Sanpera et al. 1997). This high ratio is probably due to the major use of terrestrial food by yellow-legged gulls from the former colony (mostly waste foodi Bosch et al. 1994).

The interspecific patterns in mercury levels changed between seasons, in accordance with changes in the feeding habits and the distribution of the seabirds. Indeed, those tissues reflecting the winter period showed the highest levels for the yellow-legged gull, which exploits discards extensively at this time of the year (Arcos et al. 2001). In contrast, Audouin's gull presented comparatively low levels of mercury, similar to those in the common tern. This was to be expected since most of the local breeding population of Audouin's gull migrates to the Atlantic coasts of Africa (see Oro 1998), where mercury levels in biota are lower than those in the Mediterranean (e.g. Lambertini 
\& Leonzio 1986, Osborn 1988, Renzoni et al. 1998). Furthermore, Audouin's gulls remaining in the study area shift from exploiting discards to mainly feeding upon epipelagic fish at night out of the breeding season (Arcos et al. 2001), thus reducing their intake of mercury. The small but well defined group of outliers could correspond to birds wintering in the Mediterranean, compared to those migrating into the Atlantic. Alternatively, these outliers could correspond to birds either still exploiting preferentially discards in winter or partly feeding offshore upon mesopelagic fish at night, when these prey ascend to the surface (e.g. Whitehead et al. 1996).

In spite of the high levels of mercury exhibited by fish and seabirds in our study, apparently related with the comparatively high methylation rates detected in the Mediterranean (Cossa et al. 1997), mesopelagic fish and their seabird predators would be expected to present even higher levels of this metal. Indeed, methylation processes are especially relevant in the subthermocline waters of the open oceans (mesopelagic environments), where low oxygen conditions favour those microorganisms that transform inorganic mercury into organic forms (Mason \& Fitgerald 1990, Cossa et al. 1994, Monteiro et al. 1996). Concentrations of mercury in Mediterranean and Atlantic populations of Cory's shearwater Calonectris diomedea, a seabird considered to extensively feed upon mesopelagic prey at night (Klomp \& Furness 1992), support this idea. Indeed, Renzoni et al. (1986) found mean values of mercury in liver tissues of Cory's shearwater ranging from 49.6 to $86.1 \mathrm{\mu g} \mathrm{g}^{-1}$ in 3 Mediterranean populations, values clearly higher than the $12.5 \mu \mathrm{g} \mathrm{g}^{-1}$ exhibited by an Atlantic population. At the same time, the values found in Mediterranean populations of this shearwater clearly surpass those found in the more coastal seabirds considered in the present study. Further research efforts should be directed at ascertaining the levels of mercury presented by Mediterranean mesopelagic biota and their seabird predators. Particularly, this would be interesting to assess the possible role of trawlers in providing mesopelagic fish to seabirds in areas of narrow continental shelf, where these vessels operate extensively in the mid-continental slope (at depths up to $800 \mathrm{~m}$ ) targeting on deepwater crustaceans (e.g. Demestre \& Martín 1993).

In summary, results supported our predictions. Firstly, non-epipelagic (demersal) fish showed higher levels of mercury than epipelagic fish. Secondly, discards presented on average higher levels of mercury than the typical natural prey of surface-feeding seabirds (i.e. epipelagic fish). Thirdly, surface-feeding seabirds exploiting discards incorporate more mercury than those feeding in a natural way (i.e. feeding upon either epipelagic fish or non-marine prey). The shag was the only species in our study with diving abilities (i.e. with direct access to benthic fish), and presented levels of mercury similar to those found in seabirds that consume discards. Finally, seasonal changes in mercury levels (i.e. differences between subsequent samples) were related to changes in the seabirds' feeding habits and distribution. Our findings should be taken into account when using feathers to study historical and geographical patterns of mercury pollution (e.g. Furness 1993), as the consumption of discards is a relatively new phenomenon that could differ in extent between populations (see Tasker et al. 2000). Thus, changes attributed to either spatial or temporal differences in mercury levels in the environment could be confused with differences in the use of discards by seabirds. Moreover, the selection of the feathers considered for analysis should be made carefully, paying special attention to the moult cycle and the migration pattern of the species considered for study. It is also worth to note that, although there is no evidence for toxicological effects of mercury in the study area (cf. Sanpera et al. 2000), high accumulation of this metal as a result of discards consumption could pose a threat to some seabirds, especially in association with local pollution events. This would be especially important for species that have most of the breeding populations concentrated in a few localities, as is the case of Audouin's gull (Oro 1998).

Acknowledgements. We would like to thank the skippers J. Llambrich ('Na Marinada'), A. Cruelles ('Cruelles-Montserrat') and J. Fàbrega ('Germans Fàbrega'), as well as their crews, for their help and support during the collection of discard samples at sea. D. Oro, A. Hernández, M. A. Franch (Parc Natural Delta de l'Ebre), and M. Pomarol (Torreferrusa, Generalitat de Catalunya) kindly provided the seabird corpses selected for analysis. Thanks also to D. Oro, C. Sanpera, L. Jover and M. Roura for their support and assessment. Three anonymous referees reviewed a previous version of this manuscript. This study was conducted within the frame of the research projects LIFE B4-3200/96/502 (funded by the European Commission and the DARP-Generalitat de Catalunya) and BOS2000-0569-C02-01 (funded by the Ministerio de Ciencia y Tecnología). J.M.A. was also supported by a fellowship from the DURSI-Generalitat de Catalunya (FI/FIAP'98). The University of Glasgow provided logistic support during the laboratory work. R.W.F. was funded by IFOMA.

\section{LITERATURE CITED}

Arcos JM, Oro D (2002) Significance of nocturnal purse seine fisheries for seabirds: a case study off the Ebro Delta (NW Mediterranean). Mar Biol (in press)

Arcos JM, Oro D, Sol D (2001) Competition between the yellow-legged gull Larus cachinnans and Audouin's gull Larus audouinii associated to commercial fishing vessels: the influence of season and fishing fleet. Mar Biol 139: $807-816$ 
Bearhop S, Waldron S, Thompson DR, Furness RW (2000a) Biomagnification of mercury in Great Skua Catharacta skua chicks: the influence of trophic status as determined by stable isotope signatures of blood and feathers. Mar Pollut Bull 40:181-185

Bearhop S, Phillips RA, Thompson DR., Waldron S, Furness RW (2000b) Variability in mercury concentrations of great skuas Catharacta skua: the influence of colony, diet and trophic status inferred from stable isotope signatures. Mar Ecol Prog Ser 195:261-268

Bearhop S, Ruxton GD, Furness RW (2000c) Dynamics of mercury in the blood and feathers of great skuas. Environ Toxicol Chem 19:1638-1643

Bosch M, Oro D, Ruiz X (1994) Dependence of Yellow-legged Gulls (Larus cachinnans) on food from human activity in two Western Mediterranean colonies. Avocetta 18: 135-139

Braune BM (1987) Comparison of total mercury levels in relation to diet and molt for nine species of marine birds. Arch Environ Contam Toxicol 16:217-224

Braune BM, Gaskin DE (1987) Mercury levels in Bonaparte's Gulls Larus philadelphia during autumn molt in the Quoddy region, New Brunswick, Canada. Arch Environ Contam Toxicol 16:539-549

Bryan GW (1979) Bioaccumulation of marine pollutants. Philos Trans R Soc Lond B Biol Sci 286:483-505

Cossa D, Martín JM, Sanjuan J (1994) Dimethylmercury formation in the Alboran Sea. Mar Pollut Bull 28:381-384

Cossa D, Martín JM, Takayanagi K, Sanjuan J (1997) The distribution and cycling of mercury species in the western Mediterranean. Deep-Sea Res Part II 44:721-740

Demestre M, Martín P (1993) Optimum exploitation of a demersal resource in the western Mediterranean: the fishery of the deep-water shrimp Arsiteus antennatus (Risso, 1816). Sci Mar 57:175-182

Furness RW (1993) Birds as monitors of pollutants. In: Furness RW, Greenwood JJD (eds) Birds as monitors of environmental change. Chapman \& Hall, London, p 86-143

Furness RW, Muirhead SJ, Woodburn M (1986) Using bird feathers to measure mercury in the environment: relationship between mercury content and moult. Mar Pollut Bull $17: 27-30$

Furness RW, Hudson AV, Ensor K (1988) Interactions between scavenging seabirds and commercial fisheries around the British Isles. In: Burger J (ed) Seabirds and other marine vertebrates. Competition, predation and other interactions. Columbia University Press, New York, p 240-268

Furness RW, Ensor K, Hudson AV (1992) The use of fishery waste by gull populations around the British Isles. Ardea 80:105-113

Furness RW, Thompson DR, Becker PH (1995) Spatial and temporal variation in mercury contamination of seabirds in the North Sea. Helgol Meeresunters 49:605-615

Garthe S, Camphuysen CJ, Furness RW (1996) Amounts of discards by commercial fisheries and their significance as food for seabirds in the North Sea. Mar Ecol Prog Ser 136: $1-11$

Grant PJ (1986) Gulls: a guide to identification. T \& AD Poyser, Calton

Honda K, Nasu T, Tatsukawa R (1986) Seasonal changes in mercury accumulation in the Black-eared Kite, Milvus migrans lineatus. Environ Pollut Ser A Ecol Biol 42:325-334

Irzaola M, Lucchetti A, Lleonart J, Ocaña A, Tàpia JM, Tudela S (1996) La pesca en el siglo XXI: Propuestas para una gestión pesquera racional en Catalunya. Comissions Obreres-Centre de Formació i Promoció Professional and Fundación para la Formación Contínua, Barcelona
Klomp NI, Furness RW (1992) Patterns of chick feeding on Cory's Shearwaters and the associations with ambient light. Colon Waterbirds 15:95-102

Lambertini M, Leonzio C (1986) Pollutant levels and their effects on Mediterranean seabirds. In: MEDMARAVIS, Monbailliu X (eds) Mediterranean marine avifauna. NATO ASI Series Vol G 12. Springer-Verlag, Berlin, p 359-378

Leonzio C, Fossi C, Focardi S (1986) Lead, mercury, cadmium and selenium in two species of gull feeding on inland dumps, and in marine areas. Sci Total Environ 57:121-127

Leonzio C, Lambertini M, Massi A, Focardi S, Fossi C (1989) An assessment of pollutants in eggs of Audouin's Gull (Larus audouinii) a rare species of the Mediterranean Sea. Sci Total Environ 78:13-22

Lewis SA, Furness RW (1991) Mercury accumulation and excretion in laboratory reared black-headed gulls Larus ridibundus chicks. Arch Environ Contam Toxicol 21: $316-320$

Lindqvist O (1991) Mercury in the Swedish environment, recent research on causes, consequences and corrective methods. Water Air Soil Pollut 55:1-261

Luoma SN (1990) Processes affecting metal concentrations in estuarine and coastal marine sediments. In: Furness RW, Rainbow PS (eds) Heavy metals in the marine environment. CRC Press, Florida, p 51-66

Mason RP, Fitzgerald WF (1990) Alkylmercury species in the equatorial pacific. Nature 347:457-459

Mikac N, Picer M (1985) Mercury distribution in a polluted marine area. Concentrations of methyl mercury in sediments and some marine organisms. Sci Total Environ 43: $27-39$

Monteiro LR, Furness RW (2001) Kinetics, dose-response, and excretion of methylmercury in free-living adult Cory's shearwaters. Environ Sci Technol 35:739-746

Monteiro LR, Costa V, Furness RW, Santos RS (1996) Mercury concentrations in prey fish indicate enhanced bioaccumulation in mesopelagic environments. Mar Ecol Prog Ser 141:21-25

Monteiro LR, Granadeiro JP, Furness RW (1998) Relationship between mercury levels and diet in Azores seabirds. Mar Ecol Prog Ser 166:259-265

Monteiro LR, Granadeiro JP, Furness RW, Oliveira P (1999) Contemporary patterns of mercury contamination in the Portuguese Atlantic inferred from mercury concentrations in seabird tissues. Mar Environ Res 47:137-156

Morera M, Sanpera C, Crespo S, Jover L, Ruiz X (1997) Interand intraclutch variability in heavy metals and selenium levels in Audouin's Gull eggs from the Ebro Delta, Spain. Arch Environ Contam Toxicol 33:71-75

Nisbet ICT (1994) Effects of pollution on marine birds. In: Nettleship DN, Burger J, Gochfeld M (eds) Seabirds on islands: threats, case studies and action plans. Birdlife Conservation Series 1. Birdlife International, Cambridge, p 8-25

Nriagu JO (1989) A global assessment of natural sources of atmospheric trace metals. Nature 338:47-49

Olsen KM, Larsson H (1995) Terns of Europe and North America. Christopher Helm, London

Oro D (1998) Audouin's Gull Larus audouinii. In: Ogilvie MA (ed) The birds of the Western Palearctic updated, Vol 2. Oxford University Press, Oxford, p 47-61

Oro D (1999) Trawler discards: a threat or a resource for opportunistic seabirds? In: Adams NJ, Slotow RH (eds) Proc 22 Int Ornithol Congr. Birdlife South Africa, Johannesburg, p 717-730

Oro D, Ruiz X (1997) Exploitation of trawler discards by 
breeding seabirds in the north-western Mediterranean: differences between the Ebro Delta and the Balearic Islands areas. ICES J Mar Sci 54:695-707

Oro D, Bosch M, Ruiz X (1995) Effects of a trawling moratorium on the breeding success of the yellow-legged gull Larus cachinnans. Ibis 137:547-549

Oro D, Ruiz X, Jover L, Pedrocchi V, González-Solís J (1997) Diet and adult time budgets of Audouin's Gull Larus audouinii in response to changes in commercial fisheries. Ibis 139:631-637

Osborn D (1988) Lead and mercury in the Mediterranean. In: Schmidtke NW (ed) Toxic contamination in large lakes. Vol 1: Chronic effects of toxic contaminants in large lakes. Lewis Publishers, Boca Raton, FL, p 239-255

Renzoni A, Focardi S, Fossi C, Leonzio C, Mayol J (1986) Comparison between concentrations of mercury and other contaminants in eggs and tissues of Cory's Shearwater Calonectris diomedea collected on Atlantic and Mediterranean Islands. Environ Pollut Ser A Ecol Biol 40: $17-35$

Renzoni A, Zino F, Franchi E (1998) Mercury levels along the food chain and risk for exposed populations. Environ Res 77:68-72

Sanchiz A, García-Carrascosa AM, Pastor A (2000) Heavy metal contents in soft-bottom marine macrophytes and sediments along the Mediterranean coast of Spain. PSZN I: Mar Ecol 21:1-16

Salat J (1996) Review of hydrographic environmental factors that may influence anchovy habitats in northwestern Mediterranean. Sci Mar 60 (Suppl 2), p 21-32

Sanpera C, Morera M, Crespo S, Ruiz X, Jover L (1997) Trace elements in clutches of Yellow-legged Gulls, Larus

Editorial responsibility: Otto Kinne (Editor),

Oldendorf/Luhe, Germany cachinnans, from the Medes Islands, Spain. Bull Environ Contam Toxicol 59:757-762

Sanpera C, Morera M, Ruiz X, Jover L (2000) Variability of mercury and selenium levels in clutches of Audouin's Gulls (Larus audouinii) breeding at the Chafarinas Islands, Southwest Mediterranean. Arch Environ Contam Toxicol 39:119-123

Scheuhammer AM $(1987)$ The chronic toxicity of aluminium, cadmium, mercury, and lead in birds: a review. Environ Pollut 46:263-295

Stoehr AM (1999) Are significance thresholds appropriate for the study of animal behaviour? Anim Behav 57:F22-F25

Tasker ML, Camphuysen CJ, Cooper J, Garthe S, Montevecchi WA, Blaber SJM (2000) The impacts of fishing on marine birds. ICES J Mar Sci 57:531-547

Thompson DR (1990) Mercury levels in marine vertebrates. In: Furness RW, Rainbow PS (eds) Heavy metals in the marine environment. CRC Press Inc, Boca Raton, FL, p 143-182

Thompson DR (1996) Mercury in birds and terrestrial mammals. In: Beyer WN, Heinz GH, Redman-Norwood AW (eds) Environmental contaminants in wildlife: interpreting tissue concentrations. Lewis Publishers, Boca Raton, FL, p 341-356

Walsh PM (1990) The use of seabirds as monitors of heavy metals in the marine environment. In: Furness RW, Rainbow PS (eds) Heavy metals in the marine environment. CRC Press Inc, Boca Raton, FL, p 183-204

Whitehead PJB, Bauchot ML, Hureau JC, Nielsen J, Tortonese E (1986) Fishes of the North-eastern Atlantic and the Mediterranean. UNESCO, Paris

Zar JH (1996) Biostatistical analysis. Prentice-Hall, New York

Submitted: May 25, 2001; Accepted: October 9, 2001

Proofs received from author(s): April 10, 2002 